\title{
Analysis the Profitability of Private Commercial Banks in Bangladesh
}

\author{
Parul Akhter \\ School of Business, Ahsanullah University of Science and Technology, Tejgaon, Dhaka-1208, Bangladesh
}

\begin{abstract}
The study intended to evaluate the profitability in private commercial banks in Bangladesh. This study considered 10 year dataset for the period of 2008 to 2017. The study used regression and correlation analysis tools to assess the collected data. The paper showed that return on assets, return on equity, and net interest margin were influencing the profitability of private commercial banks. This study also presented that return on assets, return on equity, and net interest margin were important association with the independent variable of equity asset ratio.
\end{abstract}

Keyword: Evaluate, return on assets, return on equity, net interest margin regression, and correlation analysis.

DOI: $10.7176 / \mathrm{EJBM} / 11-35-03$

Publication date: December $31^{\text {st }} 2019$

\section{Introduction}

Banking structure has a vital part of working monetary actions in a country. The country economic situation controls on the accuracy of the structure of bank (Teker, et al., 2011; and Kiganda, 2014; Sharma, and Kumar, 2013). The bank is an important to a country for running the economic condition. The economic activities of a country cannot be operated without a banking system (Stankeviciene and Mencaite, 2012; Albulescu, 2015). The bank as a fuel of the engine for development of a country because it is providing financial support for starting the business; providing loan facilities for increasing the production; providing financial support for modern trade; providing capital for infrastructure development and innovation; providing support for foreign trade; managing money supply; caring people's money; influencing people's savings and expenditure (Aspal and Malhotra, 2013). The financial institutions are the growing sectors in Bangladesh.

At present, Bangladesh has fifty-seven scheduled banks; there are four categories of banking systems - the public commercial banks, private commercial banks, the public development financial institutions, and foreign commercial banks. Bangladesh Bank is the central bank of Bangladesh. Bangladesh bank is controlling the all types of bank in Bangladesh. At present total number of bank branches are 9720 (Bangladesh Bank, Annual Report, 2017-2018). The banking sector has faced competition; banks are trying to provide better customer services to improve the customer satisfaction (Uppal, 2010). Banks are providing services to their customers; performance of banks depends on their service quality. Banks performance evaluation presents the actual customer satisfaction level. Evaluation of bank performance is the highest priority in Bangladesh (Siddique \& Islam, 2001). The banking sector efficient means country become more competitive in the domestically and internationally. The banking sector is generating employment opportunities and increasing the income of the country. Banking sector requires appropriate evaluation in operationally and financially (Chowdhury, 2002; and Capraru, 2014). Performance evaluation presents the growth rate of the banking sector. Performance evaluation is the vital part for all types of banks. This study tries to assess the profitability of private commercial banks of Bangladesh. It will help the managers, academicians, shareholders and researchers to develop their knowledge about the genuine performance of private commercial banks.

\section{Literature Review}

Alkhatib and Harsheh (2012) evaluated the economic performance of commercial banks of Palestinian. The study used economic, market and internal based performance of banks. They applied multiple regression and correlation analysis tools for evaluating the banks' performance. They showed that there was a statistical significant association among operational efficiency, bank size, asset management and credit risk analysis.

Basir (2000) analyzed the performance of Middle-Eastern's Islamic banks. He used secondary data (1993 to 1998). He used Return on Assets, Return on Equity, Non-Interest Margin, and Before Tax Profit. The researcher found that affirmative and statistical significant correlation among profitability, loans and equity. He also found that the macroeconomic situations definitely influence the profitability of Islamic Banks.

Sangmi and Nazir (2010) investigated the economic performance of the northern Indian Banks. They considered two banks. They used the camel model for evaluating the performance of two banks. They highlighted that both banks had sound and adequate with value to capital capability, management ability, asset superiority, and liquidity.

Roy and Khan (2013) analyzed the performance of ten commercial banks in Bangladesh. They used three variables such as product quality, service quality, and social responsibility for evaluating the performance of 
commercial banks. They applied correlation and regression analysis for assessing the hypothesis of performance of commercial banks. They found that the correlation analysis tool carried all hypotheses; however the regression analysis tool did not maintain the all hypothesis. They also found that the quality of product and service, and social responsibility had a statistical significant relationship with the bank reputation.

Almazari (2011) analyzed the economic performance of commercial banks of Jordanian. He used secondary data for the period 2005 to 2009 . He considered financial variables and ratios for evaluating the performance. He applied the simple regression method to determine the effect of operational effectiveness, asset management and bank size on return on assets and interest income. He showed that there was an important positive relationship with these variables.

Kosmidou and Zopounidis (2008) investigated the performance of Greece commercial banks and cooperative banks. They found that commercial banks are more efficient than cooperative banks. Commercial banks were attracting customers for maximizing profits, but co-operative banks did not do this.

Stankeviciene and Mencaite (2012) evaluated the performance of banks in Lithuanian. They used the systematic level method for assessing the banks' performance of Lithuanian. They indicated leading positions of the banks.

Aspal and Malhotra (2013) analyzed the public banks' economic performance of India. They used the CAMEL model for evaluating the bank's performance. They used secondary data from 2007-2011. They presented that Bank of Baroda was the leader in the fields of asset quality, and liquidity. They also found that Bank of Baroda was the second place in the areas of capital adequacy and administration efficiency and earning superiority.

\section{Objectives of the Study}

The study tried to assess the private commercial banks' profitability in Bangladesh. Following were the specific objectives:

- To assess the private commercial banks' profitability in Bangladesh.

- To identify the influential factors of banks' profitability of the private commercial banks in Bangladesh.

\section{Data and Methodology}

The study used secondary data. The data were collected from journals, internet and annual report, etc. This study included financial data, such as Return on Equity (ROE), Return on Asset (ROA), Net Interest Margin (NIM), Equity Asset Ratio (EAR), Loan Asset Ratio (LAR), and Deposit Asset Ratio (DAR). The study used a purposive sampling method to select the sample of private commercial banks. This study considered 11 commercial banks in Bangladesh. The data evaluated by using SPSS (Statistical Package for Social Sciences). The study applied regression analysis and correlation analysis tools for evaluating the profitability of private commercial banks in Bangladesh.

Conceptual model for the profitability of private commercial banks

\section{Model: 1}

Independent Variables

- $\quad$ Equity Asset Ratio (EAR)

- Loan Asset Ratio (LAR)

- Deposit Asset Ratio (DAR)

Model: 2

Independent Variables

- Equity Asset Ratio (EAR)

- Loan Asset Ratio (LAR)

- Deposit Asset Ratio (DAR)

Model: 3

Independent Variables

- Equity Asset Ratio (EAR)

- Loan Asset Ratio (LAR)

- Deposit Asset Ratio (DAR)
Dependent Variable

Return on Assets (ROA)

Return on Equity (ROE)

Dependent Variable

Dependent Variable

Net Interest Margin (NIM) 
The equation of model

$Y=\alpha+\beta_{1} X_{1}+\beta_{2} X_{2}+\beta_{3} X_{3}+\mathrm{e}$

Here,

$\mathrm{Y}=$ Return on Assets/Return on Equity/Net Interest Margin

$\mathrm{X}_{1}=$ Equity Asset Ratio

$\mathrm{X}_{2}=$ Loan Asset Ratio

$\mathrm{X}_{3}=$ Deposit Asset Ratio

$\alpha=$ Term of Intercept

$\beta=$ Coefficient of Beta

$\mathrm{e}=$ Term of Error

The study developed the following hypotheses for the regression analysis tool:

H01- Equity asset ratio is a significant, influential factor of private commercial bank's profitability.

H02-Loan asset ratio is a significant, influential factor of private commercial bank's profitability.

H03- Deposit asset ratio is a significant influential factor of private commercial banks profitability.

The study developed the following hypotheses for correlation analysis tool:

$\mathrm{H} 01=$ there is a significant correlation between the profitability of private commercial banks.

\section{Analyzing and Findings}

5.1 Results for Regression Analysis

Table 1: Private Commercial Banks Return on Assets (ROA)

\begin{tabular}{|l|l|r|r|r|c|c|}
\multicolumn{7}{|c|}{ ANOVA $^{\mathrm{a}}$} \\
\hline \multicolumn{2}{|l|}{ Model } & Sum of Squares & Df & Mean Square & F & Sig. \\
\hline \multirow{3}{*}{1} & Regression & .224 & 3 & .075 & 7.813 & $.017^{\mathrm{b}}$ \\
\cline { 2 - 4 } & Residual & .057 & 6 & .010 & & \\
\cline { 2 - 5 } & Total & .282 & 9 & & & \\
\hline
\end{tabular}

a. Predictors: (Constant), Deposit Asset Ratio, Loan Asset Ratio, Equity Asset Ratio.

b. Dependent Variable: Return on Assets (ROA)

c. The estimated R square: .796

\begin{tabular}{|c|c|c|c|c|c|c|}
\hline & & \multicolumn{5}{|c|}{ Coefficients $^{\mathrm{a}}$} \\
\hline \multirow{2}{*}{\multicolumn{2}{|c|}{ Model }} & \multicolumn{2}{|c|}{ Unstandardized Coefficients } & \multirow{2}{*}{\begin{tabular}{|c|} 
Standardized Coefficients \\
Beta
\end{tabular}} & \multirow[b]{2}{*}{$\mathrm{T}$} & \multirow[b]{2}{*}{ Sig. } \\
\hline & & B & Std. Error & & & \\
\hline 1 & (Constant) & -2.520 & .869 & & -2.901 & .027 \\
\hline & EAR & .663 & .212 & 1.166 & 3.126 & .020 \\
\hline & LAR & -.009 & .011 & -.189 & -.851 & .427 \\
\hline & DAR & -.008 & .011 & -.233 & -.692 & .515 \\
\hline
\end{tabular}

a. Dependent Variable: Return on Asset

Table 1 presented estimated $\mathrm{R}$ square was .796; representing that $79.6 \%$ changes were occurred by the independent variables to the dependent variable (ROA). The independent variable (EAR) had an important and positive connection with the dependent variable (ROA). In this study, equity asset ratio's beta coefficient was .663 and the level of significance was 0.020. However, the hypothesis H01 was accepted; hypotheses H02 and $\mathrm{H} 03$ were rejected in the case of return on assets (ROA).

Table 2: Private Commercial Banks Return on Equity (ROE)

$\mathrm{ANOVA}^{\mathrm{a}}$

\begin{tabular}{|l|l|r|r|r|c|c|}
\hline \multicolumn{2}{|l|}{ Model } & Sum of Squares & Df & Mean Square & F & Sig. \\
\hline \multirow{3}{*}{1} & Regression & 10.219 & 3 & 3.406 & 6.895 & $023^{\mathrm{b}}$ \\
\cline { 2 - 6 } & Residual & 2.964 & 6 & .494 & & \\
\cline { 2 - 6 } & Total & 13.184 & 9 & & & \\
\hline
\end{tabular}

a. Predictors: (Constant), Deposit Asset Ratio, Loan Asset Ratio, Equity Asset Ratio.

b. Dependent Variable: Return on equity (ROE)

c. The estimated R square: .775 


\begin{tabular}{|c|c|c|c|c|c|c|}
\hline \multicolumn{7}{|c|}{ Coefficients $^{\mathrm{a}}$} \\
\hline & \multirow[b]{2}{*}{ Model } & \multicolumn{2}{|c|}{ Unstandardized Coefficients } & \multirow{2}{*}{$\frac{\text { Standardized Coefficients }}{\text { Beta }}$} & \multirow[b]{2}{*}{$\mathrm{T}$} & \multirow[b]{2}{*}{ Sig. } \\
\hline & & $\mathrm{B}$ & Std. Error & & & \\
\hline \multirow[t]{4}{*}{1} & (Constant) & -15.893 & 6.240 & & -2.547 & .044 \\
\hline & EAR & 3.881 & 1.523 & & 2.549 & .044 \\
\hline & LAR & -.004 & .075 & .999 & -.052 & .960 \\
\hline & DAR & -.032 & .081 & -.012 & -.391 & .709 \\
\hline
\end{tabular}

Dependent Variable: Return on Equity

Table 2 showed estimated $\mathrm{R}$ square was .775 , representing that $77.5 \%$ changes were occurred by the independent variables to the dependent variable (ROE). The independent variable (EAR) had an important and positive connection with the dependent variable (ROE). In this study, equity asset ratio's beta coefficient was 3.881 and the level of significance was 0.044 . Therefore, the hypothesis H01 was accepted; hypotheses H02 and $\mathrm{H} 03$ were rejected in the case of return on equity (ROE).

Table 3: Commercial Banks Net Interest Margin (NIM)

\begin{tabular}{|c|c|c|c|c|c|c|}
\hline \multicolumn{7}{|c|}{ ANOVA $^{a}$} \\
\hline & odel & Sum of Squares & Df & Mean Square & $\mathrm{F}$ & Sig. \\
\hline \multirow[t]{3}{*}{1} & Regression & 3.906 & 3 & \multirow{3}{*}{$\begin{array}{r}1.302 \\
.145\end{array}$} & \multirow[t]{3}{*}{8.973} & \multirow[t]{3}{*}{$.012^{\mathrm{b}}$} \\
\hline & Residual & .870 & 6 & & & \\
\hline & Total & 4.776 & 9 & & & \\
\hline
\end{tabular}

a. Predictors: (Constant), Deposit Asset Ratio, Loan Asset Ratio, Equity Asset Ratio.

b. Dependent Variable: Net Interest Margin (NIM)

c. The estimated R square: .818

Coefficients $^{\mathrm{a}}$

\begin{tabular}{|c|c|c|c|c|c|c|}
\hline \multirow{2}{*}{\multicolumn{2}{|c|}{ Model }} & \multicolumn{2}{|c|}{ Unstandardized Coefficients } & \multirow{2}{*}{$\begin{array}{c}\text { Standardized Coefficients } \\
\text { Beta }\end{array}$} & \multirow[b]{2}{*}{$\mathrm{T}$} & \multirow[b]{2}{*}{ Sig } \\
\hline & & $\mathrm{B}$ & Std. Error & & & \\
\hline \multirow[t]{4}{*}{1} & (Constant) & -12.203 & 3.381 & & -3.609 & .011 \\
\hline & EAR & 2.250 & .825 & .962 & 2.727 & .034 \\
\hline & LAR & -.001 & .041 & -.004 & -.018 & .986 \\
\hline & DAR & -.009 & .044 & -.068 & -.213 & .838 \\
\hline
\end{tabular}

Dependent Variable: Net Interest Margin

Table 3 presented estimated $\mathrm{R}$ square was .818 , representing that $81.8 \%$ changes were occurred by the independent variables to the dependent variable (NIM). The independent variable (EAR) had an important and positive connection with the dependent variable (NIM). In this study, equity asset ratio's beta coefficient was 2.250 and the level of significance was 0.034. However, the hypothesis H01 was accepted; hypotheses H02 and $\mathrm{H} 03$ were rejected in the case of net interest margin (NIM).

\subsection{Results for Correlation Analysis}

Table 4: Correlations for Dependent Variable (Return on Assets)

\begin{tabular}{|lc|c|c|c|c|}
\hline & & ROA & EAR & LAR & DAR \\
\hline ROA & Pearson Correlation & 1 & $.873^{* *}$ & .347 & $.670^{*}$ \\
& Sig. (2-tailed) & & .001 & .325 & .034 \\
& $\mathrm{~N}$ & 11 & 11 & 11 & 11 \\
\hline EAR & Pearson Correlation & $.873^{* *}$ & 1 & .528 & $.830^{* *}$ \\
& Sig. (2-tailed) & .001 & & .117 & .003 \\
& $\mathrm{~N}$ & 11 & 11 & 11 & 11 \\
\hline LAR & Pearson Correlation & .347 & .528 & 1 & .343 \\
& Sig. (2-tailed) & .325 & .117 & & .332 \\
& N & 11 & 11 & 11 & 11 \\
\hline DAR & Pearson Correlation & $.670^{*}$ & $.830^{* *}$ & .343 & 1 \\
& Sig. (2-tailed) & .034 & .003 & .332 & \\
& $N$ & 11 & 11 & 11 & 11 \\
\hline
\end{tabular}

**. Connection is important at the 0.01 level (2-tailed).

*. Association is important at the 0.05 level (2-tailed)

The private commercial banks had $87 \%$ statistical significant relationship between return on asset (ROA) and equity asset ratio (EAR) at the $1 \%$ significance level. They had also $83 \%$ statistical significant relationship with equity asset ratio (EAR) and deposit asset ratio (DAR) at the $1 \%$ significance level. However, H01 hypothesis was accepted in the case of return on asset (ROA) and equity asset ratio (EAR). 
Table 5: Correlations for Dependent Variable (Return on Equity)

\begin{tabular}{|lc|c|c|c|c|}
\hline & & ROE & EAR & LAR & DAR \\
\hline ROE & Pearson Correlation & 1 & $.877^{* *}$ & .468 & $.686^{*}$ \\
& Sig. (2-tailed) & & .001 & .173 & .029 \\
& $\mathrm{~N}$ & 11 & 11 & 11 & 11 \\
\hline EAR & Pearson Correlation & $.877^{* *}$ & 1 & .528 & $.830^{* *}$ \\
& Sig. (2-tailed) & .001 & & .117 & .003 \\
& $\mathrm{~N}$ & 11 & 11 & 11 & 11 \\
\hline LAR & Pearson Correlation & .468 & .528 & 1 & .343 \\
& Sig. (2-tailed) & .173 & .117 & & .332 \\
& $\mathrm{~N}$ & 11 & 11 & 11 & 11 \\
\hline DAR & Pearson Correlation & $.686^{*}$ & $.830^{* *}$ & .343 & 1 \\
& Sig. (2-tailed) & .029 & .003 & .332 & \\
& $\mathrm{~N}$ & 11 & 11 & 11 & 11 \\
\hline
\end{tabular}

**. Connection is important at the 0.01 level (2-tailed).

*. Association is important at the 0.05 level (2-tailed)

The commercial banks had $88 \%$ statistical significant relationship between return on equity (ROE) and equity asset ratio (EAR) at the 1\% significance level. They had also $83 \%$ statistical significant relationship with equity asset ratio (EAR) and deposits asset ratio (DAR) at the 1\% significance level. Therefore, H01 hypothesis was accepted in the case of return on equity (ROE) and equity asset ratio (EAR).

Table 6: Correlations for Dependent Variable (Net Interest Margin)

\begin{tabular}{|lc|c|c|c|c|}
\hline & & NIM & EAR & LAR & DAR \\
\hline NIM & Pearson Correlation & 1 & $.904^{* *}$ & .481 & $.729^{*}$ \\
& Sig. (2-tailed) & & .000 & .159 & .017 \\
& $\mathrm{~N}$ & 11 & 11 & 11 & 11 \\
\hline EAR & Pearson Correlation & $.904^{* *}$ & 1 & .528 & $.830^{* *}$ \\
& Sig. (2-tailed) & .000 & & .117 & .003 \\
& $\mathrm{~N}$ & 11 & 11 & 11 & 11 \\
\hline LAR & Pearson Correlation & .481 & .528 & 1 & .343 \\
& Sig. (2-tailed) & .159 & .117 & & .332 \\
& $\mathrm{~N}$ & 11 & 11 & 11 & 11 \\
\hline DAR & Pearson Correlation & $.729^{*}$ & $.830^{* *}$ & .343 & 1 \\
& Sig. (2-tailed) & .017 & .003 & .332 & \\
& $\mathrm{~N}$ & 11 & 11 & 11 & 11 \\
\hline
\end{tabular}

**. Connection is important at the 0.01 level (2-tailed).

*. Association is important at the 0.05 level (2-tailed)

The private commercial banks had $90 \%$ statistical significant relationship between net interest margin (NIM) and equity asset ratio (EAR) at the 1\% significance level. They had also $83 \%$ statistical significant relationship with equity asset ratio (EAR) and deposit asset ratio (DAR) at the $1 \%$ significance level. However, H01 hypothesis was accepted in the case of net interest margin (NIM) and equity asset ratio (EAR).

\section{Conclusion}

This study evaluated the profitability of private commercial banks in Bangladesh. The study was selected eleven private commercial banks in Bangladesh as a sample for the analysis of bank's profitability. Return on asset, return on equity and net interest margin were taken as the dependent variables while the equity asset ratio (EAR), loan asset ratio (LAR) and deposit asset ratio (DAR) were taken as independent variables.

Regression results presented that H01; H02; and H03 hypotheses were accepted for dependent variables (ROA, ROE, and NIM) and independent variable (equity asset ratio). However, the commercial bank's profitability had a statistical significant relationship with the equity asset ratio of the significant level $1 \%$ (Ramlan, and Adnan, 2016).

Correlation results showed that H01 hypothesis was accepted for dependent variables (ROA, ROE, and NIM) and independent variables (EAR, and DAR). Therefore, the commercial bank's profitability had a statistical significant relationship with equity asset ratio and deposit asset ratio of the significant level $1 \%$ (Ramlan, and Adnan, 2016). On the practical aspect, the study will be useful for bankers, academicians, and policy maker for determining their assessments about the financial performance of banks.

\section{References}

Albulescu, C.T. (2015),'Banks Profitability and Soundness Indicators: a Macro Level Investigation in Emerging Countries", Procedia Economics and Finance 23(5), 203-209. 
Almazari, A. A. (2011), "Financial Performance Evaluation of Some Selected Jordanian Commercial Banks", International Research Journal of Finance and Economics 68, 50-63.

Aspal, P. K., and Malhotra, N. (2013), "Performance Appraisal of Indian Public Sector Banks", World Journal of Social Sciences 3, $71-88$.

Alkhatib, A. and Harsheh, M. (2012), "Financial Performance of Palestinian Commercial Banks", International Journal of Business and Social Science 3,175- 184.

Basir. (2000), "Determinants of Profitability in Islamic Banks: Some Evidence from the Middle East', Islamic Economic Studies 11, 31-57.

Capraru, B., IIhnatov, U. (2014), "Banks Profitability in Selected Central and East European Countries", Procedia Economics and Finance 6(9), 587-591.

Chowdhury, A. (2002), "Politics, Society and Financial Sector Reform in Bangladesh", International Journal of Social Economies 4, 963 - 988.

Kiganda, O. E. (2014), "Effect of Macroeconomic Factors on Commercial Banks Profitability in Kenya: Case of Equity Bank Limited”, Journal of Economics and Sustainable Development 5, (2).

Kosmidou, K., and Zopounidis, C. (2008), "Measurement of Bank Performance in Greece", South-Eastern Europe Journal of Economics 1, 79-95.

Ramlan, H., \& Adnan, M. S. (2016), "The Profitability of Islamic and Conventional Bank: Case Study in Malaysia', Procedia Economics and Finance 35, 359-367.

Roy, M. K., and Khan, S. H. (2013), "Study on Private Commercial Banks in Bangladesh', ASA University Review 7, 63-80.

Stankeviciene, J., and Mencaite, E. (2012), "The Evaluation of Bank Performance Using a Multicriteria Decision Making Model: A Case Study on Lithuanian Commercial Banks', Technological and Economic Development of Economy 18, 189-205.

Siddique, S. H., and Islam, A.F.M.M. (2001), "Banking Sector in Bangladesh: Its Contribution and Performance", Journal of Business Research 3, Jahangirnagar University, 16-33.

Sangmi,M. U. D., and Nazir, T. (2010), "Analyzing Financial Performance of Commercial Banks in India: Application of Camel Model", Pakistan Journal of Commerce and Social Sciences 4, 40-55.

Sharma, V.K., Kumar, A. (2013), "Assessment of Performance of Commercial Banks in India”, Indian Journal of Finance 7(12), 47-54.

Teker, S., Teker, D., and Kent. O. (2011), “Measuring Commercial Banks’ Performances in Turkey: A Proposed Model", Journal of Applied Finance \& Banking 1, 97-112.

Uppal, R. K. (2010), "Stability in Bank Income through Free-based Activities", Journal of Information Management and Business Review1, 1-8. 